\title{
FORMULASI DAN OPTIMASI BASIS GEL HPMC (HIDROXY PROPYL METHYL CELLULOSE) DENGAN BERBAGAI VARIASI KONSENTRASI
}

\author{
Mirhansyah Ardana*, Vebry Aeyni, Arsyik Ibrahim \\ Laboratorium Penelitian dan Pengembangan FARMAKA TROPIS Fakultas Farmasi \\ Universitas Mulawarman, Samarinda, Kalimantan Timur \\ *email:_mirhan@farmasi.unmul.ac.id
}

\begin{abstract}
Ideal gel formulation can be obtained by formulating some kind of gelling material, but the most important thing to note is the selection of a gelling agent. HPMC (Hidroxy Propyl Methyl Cellulose) is a gelling agent that is commonly used in the production of cosmetics and drugs, because it can producea gel that is clear, easily soluble in water, and has a low toxicity. This study aimed to obtain the concentration of HPMC as a gelling agent that has the physical stability in accordance with the stipulated requirements. Gel formulations made with HPMC concentration variation of $3 \%, 5 \%$ and $7 \%$, further evaluation of physical properties include organoleptic test, homogeneity, dispersive power, $\mathrm{pH}$, and viscosity. Evaluation gel base done for 3 weeks. The results of stability tests show the base gel with a concentration of 7\% HPMC has a good standard for viscosity, pH, dispersive power, homogeneity and organoleptic.
\end{abstract}

Key words: Gel, HPMC (hidroxy propyl methyl cellulose), gelling agent.

\begin{abstract}
ABSTRAK
Sediaan gel yang baik dapat diperoleh dengan cara memformulasikan beberapa jenis bahan pembentuk gel, namun yang paling penting untuk diperhatikan adalah pemilihan gelling agent. HPMC (Hidroxy Propyl Methyl Cellulose) merupakan gelling agent yang sering digunakan dalam produksi kosmetik dan obat, karena dapat menghasilkan gel yang bening, mudah larut dalam air, dan mempunyai ketoksikan yang rendah. Penelitian ini bertujuan untuk memperoleh konsentrasi HPMC sebagai gelling agent yang memiliki kestabilan fisika yang sesuai dengan persyaratan yang telah ditetapkan. Formulasi gel dibuat dengan variasi konsentrasi HPMC 3\%, 5\% dan 7\%, selanjutnya dilakukan evaluasi sifat fisika yang meliputi uji organoleptis, homogenitas, daya sebar, $\mathrm{pH}$, dan viskositas. Evaluasi basis gel dilakukan selama 3 minggu. Hasil yang diperoleh dari uji stabilitas menunjukan basis gel dengan konsentrasi HPMC 7\% memiliki standar yang baik untuk viskositas, $\mathrm{pH}$, daya sebar, homogenitas dan organoleptis.
\end{abstract}

Kata Kunci : Gel, HPMC (Hidroxy Propyl Methyl Cellulose), gelling agent.

\section{PENDAHULUAN}

Gel mempunyai potensi lebih baik sebagai sarana untuk mengelola obat topikal dibandingkan dengan salep, karena gel tidak lengket, memerlukan energi yang tidak besar untuk formulasi, stabil, dan mempunyai estetika yang bagus [1]. Sediaan gel yang baik dapat diperoleh dengan cara memformulasikan beberapa jenis bahan pembentuk gel, namun yang 
paling penting untuk diperhatikan adalah pemilihan gelling agent [2]. Dalam formulasi gel, komponen gelling agent merupakan faktor kritis yang dapat mempengaruhi sifat fisika gel yang dihasilkan [3].

Basis gel HPMC merupakan gelling agent yang sering digunakan dalam produksi kosmetik dan obat, karena dapat menghasilkan gel yang bening, mudah larut dalam air, dan mempunyai ketoksikan yang rendah [2]. Selain itu HPMC (Hidroxy Propyl Methyl Cellulose) menghasilkan gel yang netral, jernih, tidak berwarna, stabil pada $\mathrm{pH}$ 3-11, mempunyai resistensi yang baik terhadap serangan mikroba, dan memberikan kekuatan film yang baik bila mengering pada kulit [4]. Hasil penelitian sebelumnya menyebutkan basis HPMC memiliki kecepatan pelepasan obat yang baik, dan daya sebarnya luas [1].

Optimasi pada basis gel sangat diperlukan untuk mencari basis gel yang memiliki kestabilan fisika yang memenuhi standar atau persyaratan yang telah ditentukan. Berdasarkan uraian diatas maka penulis tertarik untuk melakukan formulasi dan optimasi basis gel HPMC (Hidroxy Propyl Methyl Cellulose) dengan berbagai konsentrasi.

\section{METODE PENELITIAN}

\section{Bahan}

$\begin{array}{lllr}\text { Bahan } & \text { yang } & \begin{array}{l}\text { digunakan } \\ \text { dalam }\end{array} \\ \text { penelitian } & \text { ini } & \text { adalah, } & \text { HPMC } \\ \text { (Hidroxy } & \text { Propyl } & \text { Methyl } & \text { Cellulose), }\end{array}$

metilparaben, propilparaben, propilenglikol dan air suling.

\section{Peralatan}

Peralatan yang digunakan dalam penelitian ini antara lain timbangan analitik (Precisa XB 220 A), Gelas kimia, magnetic stirrer, $\mathrm{pH}$ meter, Viskometer Rheosys, dan alat daya sebar.

\section{Prosedur Penelitian}

\section{Optimasi Konsentrasi Basis Gel}

Optimasi konsentrasi basis gel dilakukan dengan membuat basis gel tanpa bahan aktif, dengan cara HPMC dengan variasi konsentrasi 3\%, 5\% dan 7\% dikembangkan dengan air suling, kemudian didiamkan selama kurang lebih 24 jam, selanjutnya ditambahkan metilparaben dan propilparaben sebagai pengawet yang telah dilarutkan dalam propilenglikol sebagai humektan dan diaduk dengan bantuan stirrer dengan kecepatan 4-6 rpm hingga homogen. Selanjutnya dilakukan evaluasi kestabilan basis gel selama 3 minggu, dimana dalam 1 minggu dilakukan 2 kali pengujian stabilitas dan disimpan pada suhu ruang. Stabilitas yang di uji yaitu pengukuran viskositas, $\mathrm{pH}$, daya sebar, homogenitas dan organopetis (bau, warna, dan konsistensi). Kemudian dipilih salah satu konsentrasi HPMC yang memiliki stabilitas yang memenuhi persyaratan atau standar yang telah ditetapkan.

Tabel 1. Rancangan Formulasi Basis Gel HPMC

\begin{tabular}{cccc}
\hline \multirow{2}{*}{ Nama bahan } & \multicolumn{3}{c}{ Konsentrasi bahan dalam formula basis Gel (\%) } \\
\cline { 2 - 4 } & $\mathrm{F} 1$ & $\mathrm{~F} 2$ & $\mathrm{~F} 3$ \\
\hline HPMC & $3 \%$ & $5 \%$ & $7 \%$ \\
Propilenglikol & $15 \%$ & $15 \%$ & $15 \%$ \\
Metilparaben & $0,075 \%$ & $0,075 \%$ & $0,075 \%$ \\
Propilparaben & $0,025 \%$ & $0,025 \%$ & $0,025 \%$ \\
Air suling hingga & $150 \%$ & $150 \%$ & $150 \%$ \\
\hline
\end{tabular}




\section{Evaluasi Kestabilan Basis Gel}

Pengukuran viskositas yaitu dengan Viskometer Rheosys. Sebanyak $15 \mathrm{~mL}$ basis gel dimasukkan kedalam wadah silinder, kemudian viskositasnya diukur dengan viskometer yang dilengkapi dengan spindel (25mm Concentric Cylinders) dengan kecepatan $10 \mathrm{rpm}$.

Pengukuran $\mathrm{pH}$ sediaan dilakukan dengan menggunakan $\mathrm{pH}$ meter, dengan cara alat terlebih dahulu dikalibrasi dengan menggunakan larutan dapar standar $\mathrm{pH}$ netral $(\mathrm{pH} 7,00)$ dan larutan dapar $\mathrm{pH}$ asam (pH 4,00) hingga alat menunjukan harga $\mathrm{pH}$ tersebut. Kemudian elektroda dicuci dengan air suling, lalu dikeringkan dengan kertas tissue. Selanjutnya elektroda dicelupkan kedalam basis gel, sampai alat menunjukkan harga $\mathrm{pH}$ yang konstan. Angka yang ditunjukkan $\mathrm{pH}$ meter merupakan harga $\mathrm{pH}$ sediaan [5]. $\mathrm{pH}$ sediaan basis gel harus sesuai dengan $\mathrm{pH}$ kulit yaitu 4,5-6,5 [6]. Range $\mathrm{pH}$ normal kulit yaitu 5,0-6,8 [7].

Pengukuran daya sebar yaitu sebanyak 0,5 g sampel gel diletakan diatas kaca bulat berdiameter $15 \mathrm{~cm}$, kaca lainnya diletakan diatasnya dan dibiarkan selama 1 menit, diameter sebar gel diukur. Setelahnya, ditambahkan $150 \mathrm{~g}$ beban tambahan dan didiamkan selama 1 menit lalu diukur diameter yang konstan [8]. Daya sebar 5-7 cm menunjukkan konsistensi semisolid yang sangat nyaman dalam penggunaan [9].

Pengujian homogenitas dilakukan dengan cara mengoleskan sampel gel pada sekeping kaca atau bahan transparan lain yang cocok, sediaan harus menunjukkan susunan yang homogen dan tidak terlihat adanya butiran kasar [10].

Pengujian organoleptik dilakukan dengan cara pengamatan langsung bentuk, warna, dan bau dari gel yang dibuat. Gel biasanya jernih dengan konsistensi setengah padat [11].

\section{HASIL DAN PEMBAHASAN}

Setiap sediaan farmasi yang akan dikembangkan harus melewati tahap pengujian untuk melihat kestabilannya pada penggunaan ataupun penyimpanan jangka panjang. Pengujian kestabilan tersebut dapat berupa pengujian kestabilan secara fisika, kimia dan mikrobiologi ${ }^{[12]}$. Pada penelitian ini dilakukan uji kestabilan fisika, dimana akan dilakukan formulasi basis gel menggunakan gelling agent HPMC dengan konsentrasi berbeda yaitu $3 \%$, 5\% dan $7 \%$ dengan penyimpanan selama 3 minggu dalam 1 minggu dilakukan 2 kali pengujian kestabilan. Kestabilan fisika sediaan gel ditetapkan melalui pengamatan sifat organoleptis, homogenitas, viskositas, $\mathrm{pH}$, dan daya sebar.

Formula basis gel terdiri dari HPMC, propilenglikol, metilparaben, propilparaben dan aquades. HPMC berfungsi sebagai gelling agent yang merupakan bahan pembentuk gel. Propilenglikol berfungsi sebagai humektan yang akan menjaga kestabilan sediaan dengan cara mengabsorbsi lembab dari lingkungan dan mengurangi penguapan air dari sediaan. Selain menjaga kestabin sediaan, secara tidak langsung humektan juga dapat mempertahankan kelembaban kulit sehingga kulit tidak kering [13,14]. Metilparaben dan propilparaben berfungsi sebagai pengawet [15]. Pengawet diperlukan dalam formulasi gel karena gel memiliki kandungan air yang tinggi sehingga dapat menyebabkan terjadinya kontaminasi mikroba. Air suling berfungsi sebagai pelarut dalam formulasi gel [16]. 


\section{Pengujian Organoleptis}

Tabel 2. Hasil Pengujian Organoleptis

\begin{tabular}{cccc}
\hline \multirow{2}{*}{ Konsentrasi HPMC } & \multicolumn{3}{c}{ Organoleptis } \\
\cline { 2 - 4 } & Konsistensi & Warna & Bau \\
\hline $3 \%$ & Agak cair & Bening & Berbau bahan HPMC \\
$5 \%$ & Agak kental & Bening & Berbau bahan HPMC \\
$7 \%$ & Kental & Bening & Berbau bahan HPMC \\
\hline
\end{tabular}

Berdasarkan hasil pengamatan organoleptis yang dilakukan selama 3 minggu terhadap basis gel, diketahui bahwa basis gel dengan konsentrasi HPMC $3 \%, 5 \%$ dan $7 \%$ tidak mengalami perubahan, dimana warna yang dihasilkan bening, dan berbau bahan HPMC.
Sedangkan konsistensi basis gel HPMC 3\% agak cair, 5\% agak kental dan 7\% kental. Hal ini disebabkan karena semakin tinggi konsentrasi HPMC maka semakin kental basis gel yang diperoleh. Sehingga basis yang baik adalah konsentrasi HPMC 7\%.

\section{Pengujian Homogenitas}

Tabel 3. Hasil Pengamatan Homogenitas

\begin{tabular}{cc}
\hline Konsentrasi HPMC & Homogenitas \\
\hline $3 \%$ & Homogen, tidak ada butiran kasar \\
$5 \%$ & Homogen, tidak ada butiran kasar \\
$7 \%$ & Homogen, tidak ada butiran kasar \\
\hline
\end{tabular}

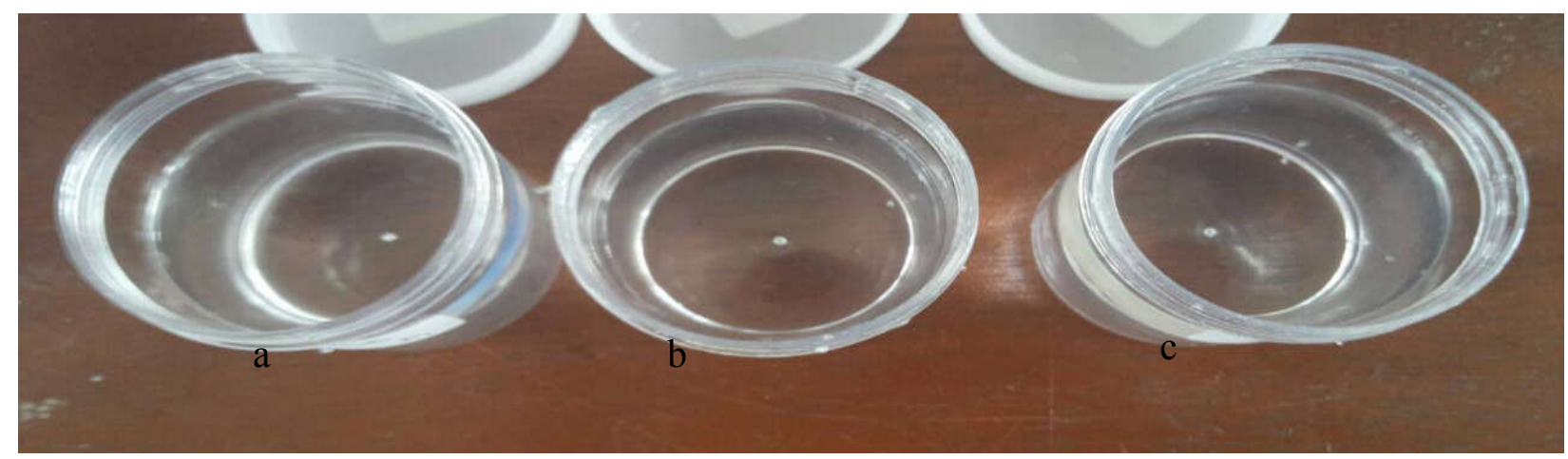

Gambar 1. Basis gel konsentrasi HPMC (a) 3\%, (b) 5\%, dan (c) 7\% (c).

Pemeriksaan homogenitas terhadap sediaan basis gel menunjukan bahwa semua sediaan tidak memperlihatkan adanya butiran kasar pada saat dilihat secara visual, tidak dilihat pada kaca transparan karena basis gel bewarna bening. Hal ini menunjukkan bahwa sediaan yang dibuat mempunyai susunan yang homogen. 


\section{Pengujian Daya Sebar}

Tabel 4. Hasil Pengukuran Daya Sebar

\begin{tabular}{ccccccccc}
\hline Konsentrasi & \multicolumn{7}{c}{ Nilai Daya Sebar (cm) } \\
\cline { 2 - 9 } HPMC & P0 & P1 & P2 & P3 & P4 & P5 & P6 & Rata-Rata \\
\hline $3 \%$ & 10.56 & 8.12 & 8.85 & 10.92 & 7.40 & 6.63 & 8.02 & 8.64 \\
$5 \%$ & 8.22 & 7.47 & 8.10 & 8.18 & 7.45 & 6.88 & 8.20 & 7.78 \\
$7 \%$ & 6.44 & 5.29 & 7.05 & 7.02 & 6.45 & 5.71 & 7.12 & 6.44 \\
\hline
\end{tabular}

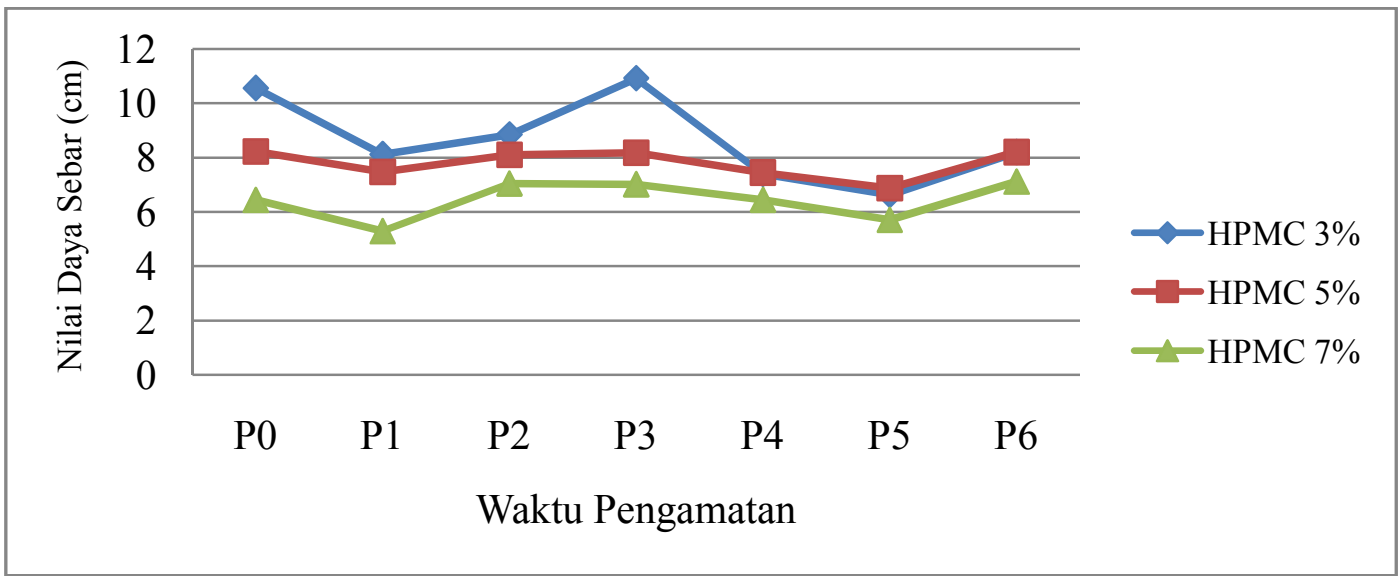

Gambar 2. Pengukuran Daya Sebar

Pengujian daya sebar bertujuan untuk mengetahui seberapa baik sediaan gel menyebar di permukaan kulit, karena dapat mempengaruhi absorbsi obat dan kecepatan pelepasan zat aktif di tempat pemakaiannya. Suatu sediaan yang baik dan lebih disukai bila dapat menyebar dengan mudah di kulit dan nyaman digunakan [17]. Daya sebar gel yang baik yaitu antara 5 sampai $7 \mathrm{~cm} \mathrm{[9].}$

Hasil rata-rata yang diperoleh untuk konsentrasi $3 \%, 5 \%$ dan $7 \%$ berturut-turut adalah $8,64 \mathrm{~cm} ; 7,78 \mathrm{~cm}$, dan $6,44 \mathrm{~cm}$. Dimana konsentrasi HPMC 7\% memenuhi persyaratan. Semakin tinggi nilai konsentrasi gelling agent yang digunakan maka akan terjadi penurunan nilai daya sebar. Penurunan nilai daya sebar ini disebabkan karena perbedaan konsentrasi HPMC pada masing-masing formula. Semakin tinggi konsentrasi gelling agent yang digunakan maka akan meningkatnya tahanan gel untuk mengalir dan menyebar [13].

\section{Pengujian pH}

Tabel 5. Hasil Pengukuran $\mathrm{pH}$

\begin{tabular}{ccccccccc}
\hline Konsentrasi & \multicolumn{10}{c}{ Nilai $\mathrm{pH}$} \\
\cline { 2 - 9 } HPMC & P0 & P1 & P2 & P3 & P4 & P5 & P6 & Rata-rata \\
\hline $3 \%$ & 6.43 & 6.45 & 6.55 & 6.37 & 6.22 & 6.18 & 6.30 & 6.35 \\
$5 \%$ & 6.51 & 6.50 & 6.33 & 6.20 & 6.18 & 6.08 & 6.34 & 6.30 \\
$7 \%$ & 6.54 & 6.50 & 6.35 & 6.45 & 6.26 & 6.36 & 6.36 & 6.40 \\
\hline
\end{tabular}


Pengukuran $\mathrm{pH}$ bertujuan untuk mengetahui apakah sediaan yang dihasilkan dapat diterima $\mathrm{pH}$ kulit atau tidak, karena hal ini berkaitan dengan keamanan dan kenyamanan sediaan ketika digunakan. Apabila tidak sesuai dengan $\mathrm{pH}$ kulit maka sediaan dapat menyebabkan iritasi yang mengakibatkan ketidaknyamanan dalam penggunaan. Berdasarkan pada hasil pengamatan dari masing-masing sediaan gel selama penyimpanan 3 minggu pada suhu ruang, dapat dilihat terjadi naik turunnya nilai $\mathrm{pH}$ pada sediaan. Tetapi perubahan $\mathrm{pH}$ tidak terjadi secara signifikan sehingga masih berada dalam range $\mathrm{pH}$ normal kulit yaitu $5,0-6,8$ [7]. Mengacu pada nilai $\mathrm{pH}$ tersebut maka tiga basis gel tersebut memenuhi persyaratan. Jika dirata-ratakan $\mathrm{pH}$ dari basis gel tersebut untuk 3\%, 5\% dan $7 \%$ berturut-turut adalah 6,$35 ; 6,30$ dan 6,40 .

\section{Pengujian Viskositas}

Tabel 6. Hasil Pengukuran Viskositas

\begin{tabular}{cccc}
\hline \multirow{2}{*}{ Pengamatan } & \multicolumn{3}{c}{ Nilai Viskositas (Pa.s) } \\
\cline { 2 - 4 } & HPMC 3\% & HPMC 5\% & HPMC 7\% \\
\hline P0 & 0,11503 & 0,75130 & 2,50215 \\
P1 & 0,12672 & 0,99452 & 3,72782 \\
P2 & 0,12417 & 1,04285 & 3,77259 \\
P3 & 0,11987 & 0,98246 & 3,21508 \\
P4 & 0,11923 & 1,02275 & 3,90050 \\
P5 & 0,10151 & 1,04459 & 3,33687 \\
P6 & 0,13084 & 1,08524 & 3,83097 \\
Rata-rata & 0,11962 & 0,98910 & 3,46942 \\
\hline
\end{tabular}

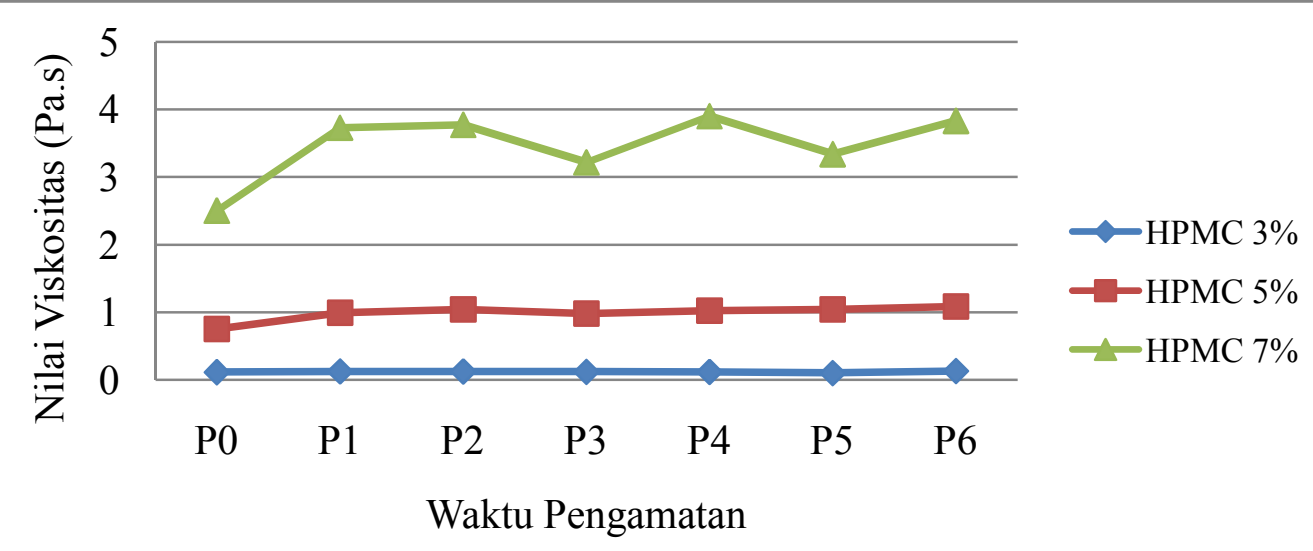

Gambar 4. Hasil Pengukuran Viskositas

Pengujian viskositas bertujuan untuk menentukan nilai kekentalan suatu zat. Semakin tinggi nilai viskositasnya maka semakin tinggi tingkat kekentalan zat tersebut [13]. Hasil yang diperoleh terjadi peningkatan viskositas pada masingmasing formula seiring meningkatnya konsentrasi HPMC yang digunakan. Untuk konsentrasi HPMC 3\% dan 5\% memiliki viskositas yang stabil sedangkan HPMC 
$7 \%$ nilai viskositasnya mengalami naik turun selama 3 minggu penyimpanan. Nilai viskositas sediaan gel yang baik yaitu 2000-4000 $\mathrm{cps}^{[9]}$. Dari rata-rata viskositas dari HPMC 3\% adalah 0,11962 Pa.s (119,62 cps), 5\% adalah 0,98910 Pa.s (989,1 cps) sedangkan 7\% adalah 3,46942 Pa.s (3496,42 cps). Sehingga yang memiliki viskositas yang baik adalah HPMC 7\%.

HPMC merupakan polimer turunan selulosa, yang pada saat terjadi disperse molekul polimer ini masuk dalam rongga yang dibentuk molekul air, sehingga terjadi ikatan hidrogen antara gugus hidroksil ($\mathrm{OH})$ dari polimer dengan molekul air. Ikatan hidrogen ini berperan dalam hidrasi pada proses swelling, sehingga makin tinggi konsentrasi HPMC maka makin banyak gugus hidroksil yang berikatan, sehingga makin tinggi viskositas ${ }^{[18]}$.

\section{KESIMPULAN}

Berdasarkan hasil penelitian yang telah dilakukan maka dapat disimpulkan bahwa basis gel dengan konsentrasi HPMC 7\% memenuhi standar atau persyaratan yang baik untuk viskositas, $\mathrm{pH}$, daya sebar, homogenitas dan organoleptis.

\section{DAFTAR PUSTAKA}

1. Madan, J., dan Singh, R. 2010. Formulation and Evaluation of Aloevera Topical Gels. Int.J.Ph.Sci. 2 (2). 551-555.

2. Setyaningrum, N.L. 2013. Pengaruh Variasi Kadar Basis HPMCDalam Sediaan Gel Ekstrak Etanolik Bunga Kembang Sepatu (Hibiscus rosa sinensis L.) Terhadap Sifat Fisika dan Daya Antibakteri pada Staphylococcus aureus. Naskah Publikasi. Fakutas Farmasi Universitas Muhammadiyah Surakarta.

3. Arikaumala, J., Dewantara, I.G.N.A., dan Wijayanti, N.P.A.D. 2013. Optimasi HPMC Sebagai Gelling
Agent Dalam Formula Gel Ekstrak Kulit Buah Manggis (Garcinia mangostan L.). Jurnal Farmasi Udayana. Jurusan Farmasi Fakultas Matematika dan Ilmu Pengetahuan Alam Universitas Udayana. Bali.

4. Suardi, M., Armenia dan Anita, M. 2008. Formulasi dan Uji Klinik Gel Antijerawat Benzoil Peroksida-HPMC. Skripsi. Fakultas Farmasi Universitas Udayana. Denpasar.

5. Rawlins, E.A. 2003. Bentleys of Pharmaceutics. Edisi Kedelapanbelas. Baillierre Tindal. London. Hal 22-35.

6. Tranggono, Retno, I., Latifah, Fatmah. 2007. Buku Pegangan Ilmu Pengetahuan Kosmetik. PT. Gramrdia Pustaka Utama. Jakarta.

7. Ansari, S.A. 2009. Skin $p H$ and Skin Flora. In Handbook of Cosmetics Science and Technology. Edisi Ketiga. Informa Healtcare USA. New York. Hal 222-223.

8. Astuti I. Y., D. Hartanti, dan A. Aminiati. 2010. Peningkatan Aktivitas Antijamur Candida albicans Salep Minyak Atsiri Daun Sirih (Piper bettle L.) Melalui Pembentukan Kompleks Inklusi dengan $\beta$-siklodekstrin. Majalah Obat Tradisional. 15: 94-99.

9. Garg, A., Aggarwal, D., Garg, S., dan Sigla, A.K. 2002. Spreading of Semisolid Formulation: An Update. Pharmaceutical Tecnology. 84-102.

10. Anonim. $1985 . \quad$ Formularium Kosmetika Indonesia. Dapertemen Kesehatan RI. Jakarta.

11. Ansel, H.C. 1989. Penghantar Bentuk Sediaan Farmasi. Edisi 4. Penerjemah: Farida Ibrahim. UI Press. Hal. 390391.

12. Ida, N., dan Noer, S.F. 2012. Uji Stabilitas Fisik Gel Ekstrak Lidah Buaya (Aloe vera L.). Majalah Farmasi dan Farmakologi. 16 (2). 7984. 
13. Martin, A.J.S., Swarbrick, dan Cammarata, A. 1993. Farmasi Fisika. Edisi 3, diterjemahkan oleh Yoshita. UI-Press. Jakarta.

14. Barel, A. O., M. Paye, dan H. I. Maibach. 2009. Handbook of Cosmetic Science and Technology. Third Edition. Informa Healthcare USA, Inc. New York. 233, 261-262.

15. Rowe, R. C., Sheskey, P. J., and Quinn, M. E. 2009. Handbook of Pharmaceutical Excipients. Sixth Edition. Pharmaceutical Press. London.

16. Anonim. 1979. Farmakope Indonesia. Edisi Ketiga. Dapertemen Kesehatan Indonesia. Jakarta.
17. Wyatt, E. L., Sutter, S. H., dan Drake, L. A. 2008. Dermatology Pharmacology; In Hardaman, J. G., Limbird, L. E., dan Gilman, A. G. (eds), Gilman's the Parmacological Basis of Therapeutics. $10^{\text {th }}$ edition. 1763. McGraw-Hill. New York.

18. Erawati, T., Rosita, N., Hendroprasetyo, W., dan Juwita, D. R., 2005, Pengaruh Jenis Basis Gel Dan Penambahan $\mathrm{NaCl}(0.5 \%$-b/b) Terhadap Intensitas Echo Gelombang Ultrasonik Sediaan Gel Untuk Pemeriksaan USG (Acoustic Coupling Agent). Airlangga Journal of Pharmacy, 5 (2). 